\title{
PENERAPAN MODEL PEMBELAJARAN HISTORIOGRAFI SOSIAL PADA MATA KULIAH SEJARAH SOSIAL DI FKIP UM METRO
}

\author{
Bobi Hidayat \& Kuswono \\ Pendidikan Sejarah FKIP Universitas Muhammadiyah Metro
}

Abstrak: Penelitian ini dilakukan pada mahasiswa Program Studi Pendidikan Sejarah yang bertujuan untuk memperbaiki kualitas pembelajaran dengan menerapkan model pembelajaran historiografi sosial pada mata kuliah sejarah sosial. Penelitian dilakukan berawal dari beberapa permasalahan yang ditemukan oleh peneliti yang sekaligus dosen pengajar yaitu kualitas pembelajaran yang kurang baik. Hal ini ditunjukkan dengan rendahnya aktivitas dan prestasi belajara mahasiswa.

Teknik pengumpulan data yang digunakan dalam penelitian ini antara lain pengamatan atau observasi, dokumentasi, wawancara, foto, dan tes. Langkah-langkah penelitian yang diambil sesuai dengan langkah-langkah dalam penelitian tindakan kelas yaitu perencanaan (planning), pelaksanaan (acting), observasi (observing), dan refleksi (reflecting). Selanjutnya data yang diperoleh dianalisis dengan menggunakan pendekatan deskriptif analitik yang bertujuan untuk mencari gambaran alamiah dari temuan penelitian dan divalidasi dengan menggunakan teknik triangulasi.

Hasil penelitian menunjukkan ada perbaikan aktivitas belajar mahasiswa dan prestasi belajar mahasiswa, serta kemampuan menulis sejarah mahasiswa menggunakan teknik historiografi juga mengalami peningkatan.

Kata kunci: Model Pembelajaran Historiografi Sosial, Aktivitas, dan Prestasi Belajar

\section{PENDAHULUAN}

Universitas Muhammadiyah

Metro merupakan salah satu lembaga pendidikan yang memiliki tugas untuk mewujudkan tujuan pendidikan. Salah satu upaya yang dilakukan adalah dengan meningkatkan kualitas pembelajaran di Jurusan dan Program Studi yang berada didalamnya.

Upaya itu didukung oleh Semua Program Studi di FKIP UM Metro. Setiap Program Studi membuat perencanaan terhadap proses pembelajaran yang dilakukan. Begitu juga dengan Program Studi Pendidikan Sejarah. Namun, 
perencanaan pembelajaran yang telah dibuat oleh program Studi Sejarah, dalam pelaksanaanya masih menemui banyak kendala.

Lebih spesifik pada mata kuliah sejarah sosial. Pembelajaran yang dilakukan dirasa masih belum optimal. Pembelajaran cenderung monoton dan membosankan. Aktivitas mahasiswa belum terlihat dengan jelas. Hal itu, dibuktikan dengan rendahnya jumlah pertanyaan yang diajukan oleh mahasiswa. Mahasiswa cenderung hanya sebagai pendengar pasif yang sulit diketahui penguasaan materi yang disampaikan. Bahkan ada juga mahasiswa yang terlihat tidur saat proses pembelajaran sedang berlangsung. Dampaknya pada prestasi belajar mahasiswa yang rendah. Hal ini diduga proses pembelajaran yang dilakukan oleh dosen pengajar belum sesuai dengan karakteristik mata kuliah tersebut.

Kondisi tersebut belum sesuai dengan tujuan pembelajaran yang sebenarnya. Idealnya pembelajaran yang dilakukan adalah menuntut mahasiswa untuk aktif dan ikut serta dalam proses pembelajaran. Mahasiswa merasa antusias dengan proses pembelajaran sehingga terlihat aktif dalam proses pembelajaran. Hal ini ini didukung oleh pendapat Karwono (2012:20) yang berpendapat bahwa pembelajaran adalah suatu proses yang diupayakan agar peserta didik dapat mengoptimalkan potensi yang dimiliki baik kognitif maupun sosioemosional secara efektif dan efisien untuk mencapai perubahan prilaku yang diharapkan.

Melihat fenomena di atas, peneliti yang sekaligus dosen pengampu mata kuliah tersebut tertarik untuk memvariasikan model pembelajaran yang dilakukan. Model yang ingin dilaksanakan adalah model pembelajaran historiografi sosial. Model pembelajaran ini dirasa cocok diterapkan dalam proses pembelajaran khususnya pada mata kuliah sejarah sosial. Model ini dirasa sesuai dengan karakteristik mata kuliah ini yang menuntut mahsiswanya mampu merekonstruksi kembali peristiwa sejarah yang berkaitan dengan masalah atau peristiwa sosial.

Adapaun tujuan penelitian ini adalah untuk mengetahui penggunaan model pembelajaran 
historiografi sosial yang dapat analitik merupakan rancangan memperbaiki aktivitas belajar pengorganisasian yang mahasiswa (2) penggunaan model dikembangkan dari kategori-kategori pembelajaran historiografi sosial yang dapat meningkatkan prestasi belajar mahasiswa.

\section{METODE PENELITIAN}

Penelitian ini adalah penelitian tindakan kelas. Penelitian tindakan kelas (classroom action research) merupakan bentuk penelitian yang bersifat reflektif dengan melakukan tindakan-tindakan tertentu agar dapat memperbaiki dan/atau meningkatkan praktikpraktik pembelajaran di kelas secara lebih profesional (Sukidin, 2008:28). Jadi penelitian ini merupakan penelitian tindakan kelas yang bersifat reflektif untuk meningkatkan kualitas pembelajaran agar lebih optimal.

Pendekatan penelitian yang digunakan adalah dengan menggunakan pendekatan deskriptif analitik. Menurut Basrowi dan Suwandi (2008:200) deskriptif yang ditemukan dari hubunganhubungan yang memenuhi syarat atau yang muncul dari data, sehingga dapat dicapai deskripsi baru. Pendekatan ini menginginkan hasil penelitian yang menghasilkan deskripsi baru atau gambaran baru dari temuan hasil penelitian yang dilakukan. Temuan baru yang dinginkan dalam penelitian ini yang juga merupakan hasil dari penelitian ini adalah hasil dari penerapan model pembelajaran historiografi sosial. Sedangkan prosedur penelitian yang digunakan meliputi perencanaan (plan), pelaksanaan (act), pengamatan (observasi), dan refleksi. Apabila siklus yang dilakukan belum sesuai dengan yang diharapkan maka akan dilanjutkan pada siklus berikutnya dengan langkah-langkah penelitian yang sama. Hal itu dapat dilihat pada gambar berikut: 


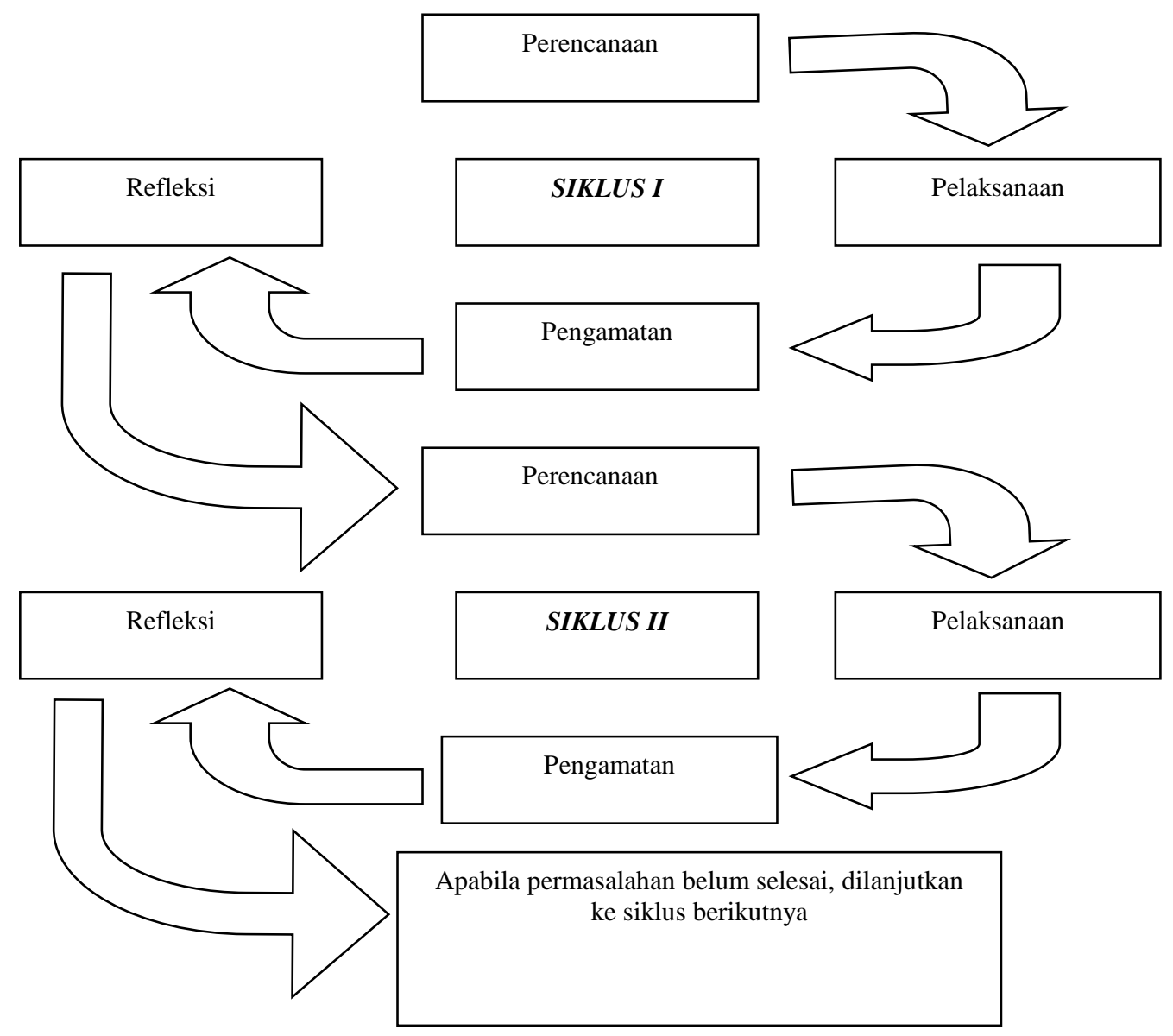

Prosedur Penelitian Tindakan Kelas (Suharsimi Arikunto, 2010:16)

Selain metode dan penelitian yang ditemukan pendekatan penelitian di atas, merupakan hasil penelitian yang penelitian ini menggunakan teknik alamiah karena mencakup aktivitas pengumpulan data antara lain dan hasil belajar di kelas.

pengamatan atau observasi, dokumentasi, wawancara, foto dan HASIL DAN PEMBAHASAN

tes. Kemudian data yang diperoleh Setelah dilakukan penelitian terkait divalidasi dengan cara triangulasi. dengan implementasi model Melalui triangulasi data akan lebih pembelajaran historiografi sosial, akurat dan akan memperkuat hasil maka dihasilkan hasil penelitian temuan dalam penelitian. Hasil sebagai berikut: 
Tabel 1. Aktivitas Belajar Mahasiswa siklus 1 dan 2

\begin{tabular}{c|c|c|c|c}
\hline \multirow{2}{*}{ No } & \multirow{2}{*}{ Kriteria } & \multicolumn{2}{|c|}{ Jumlah } & \multirow{2}{*}{ Ket. } \\
\cline { 3 - 4 } & & Siklus 1 & Siklus 2 & \\
\hline 1 & Sangat Rendah (SR) & & & Tetap \\
\hline 2 & Rendah (R) & $14 / 40,00$ & $1 / 2,86$ & Menurun \\
\hline 3 & Sedang (S) & $14 / 40,00$ & $12 / 34,28$ & Menurun \\
\hline 4 & Tinggi (T) & $6 / 17,14$ & $17 / 48,57$ & Meningkat \\
\hline 5 & Sangat Tinggi (ST) & & & Meningkat \\
\hline & & $1 / 2,86$ & $5 / 14,28$ & \\
\hline
\end{tabular}

Sumber : Hasil Penelitian Aktivitas Belajar Mahasiswa Siklus 1 dan 2

Tabel 2. Prestasi Belajar Mahasiswa siklus 1 dan 2

\begin{tabular}{c|c|c|c|c}
\hline \multirow{2}{*}{ No } & \multirow{2}{*}{ Rtng } & \multicolumn{2}{|c|}{ Jumlah Mhs/Persentase } & \multirow{2}{*}{ Ket } \\
\cline { 3 - 4 } & Nilai & Siklus 1 & Siklus 2 & Tetap \\
\hline 1 & $1-10$ & $0 / 00$ & $0 / 00$ & Tetap \\
\hline 2 & $11-20$ & $0 / 00$ & $0 / 00$ & Tetap \\
\hline 3 & $21-30$ & $0 / 00$ & $0 / 00$ & Tetap \\
\hline 4 & $31-40$ & $0 / 00$ & $0 / 00$ & Tetap \\
\hline 5 & $41-50$ & $0 / 00$ & $0 / 00$ & Menurun \\
\hline 6 & $51-60$ & $16 / 45,7$ & $0 / 00$ & Menurun \\
\hline 7 & $61-70$ & $12 / 34,2$ & $6 / 17,14$ & Menigkat \\
\hline 8 & $71-80$ & $7 / 20,0$ & $28 / 80,0$ & Meningkat \\
\hline 9 & $81-90$ & $0 / 00$ & $1 / 2,86$ & Tetap \\
\hline 10 & $91-100$ & $0 / 00$ & $0 / 00$ & $\mathbf{3 5 / 1 0 0 \%}$ \\
\hline \multicolumn{2}{r|}{ Jumlah } & $\mathbf{3 5 / 1 0 0 \%}$ & & \\
\hline
\end{tabular}

Sumber : Hasil Penelitian Prestasi Belajar Mahasiswa Siklus 1 dan 2 
Berdasarkan tabel 1 tentang aktivitas belajar mahasiswa, dapat dilihat bahwa terdapat peningkatan ktivitas belajar antara siklus pertama dan siklus pembelajaran yang kedua. Hal ini menunjukkan terdapat perbaikan proses pembelajaran pada siklus 2. Aktivitas belajar mahasiswa pada pembelajaran siklus kedua berada pada kisaran sangat rendah tetap tidak ada, sedangkan pada kisaran rendah mengalami penurunan menjadi 1, bahkan terdapat mahasiswa yang mencapai aktivitas belajar pada kisaran sangat tinggi yaitu sebanyak 5 mahasiswa pada proses pembelajaran siklus 2 . Aktivitas belajar mahasiswa pada siklus 2 menunjukkan peningkatan yang baik sehingga berdasarkan hasil diskusi dengan dosen mitra dapat diperoleh bahwa aktivitas belajar mahasiswa pada siklus 2 dapat dikatakan sudah baik.

\section{Peningktan aktivitas} pembelajaran siklus ke dua tidak terlepas dari refleksi pembelajaran siklus pertama. Hasil refleksi pembelajaran siklus pertama menjadi acuan dalam merencanakan proses pembelajaran siklus yang kedua. Hasil refleksi menunjukkan kurang perhatian dosen terhadap mahasiswa sehingga mahasiswa merasa kurang terperhatikan. Selain itu, kurangnya aktivitas belajar mahasiswa siklus pertama disebabkan karena kurangnya lembar kerja mahasiswa. Hal ini yang kemudian diperbaiki pada siklus pembelajaran yang kedua.

Sedangkan pada prestasi belajar mahasiswa, berdasarkan tabel 2 telah menunjukkan prestasi belajar yang memuaskan. Prestasi belajar mahasiswa pada siklus 2 tidak ada yang berada dibawah angka 60 sehingga prestasi belajar pada siklus 2 disimpulkan sudah dapat dikatakan baik. Hasil belajar mahasiswa yang diperoleh pada siklus kedua merupakan hasil tindakan dari perbaikan pembelajaran siklus pembelajaran sebelumnya.

Dari keseluruhan proses penelitian dan berdasarkan hasil diskusi serta berkomunikasi dengan mahasiswa melalui wawancara tentang proses pembelajaran yang telah dilaksanakan pada siklus dua, maka proses pembelajaran tidak dilanjutkan pada siklus berikutnya.

Selain aktivitas dan prestasi belajar yang dinilai, peneliti juga 
melihat kemampuan menulis sejarah mahasiswa. Menurut pengamatan peneliti, kemampuan menulis mahasiswa menggunakan langkahlangkah penulisan sejarah yang sifatnya sederhana mengalami perbaikan. Pada pembelajaran siklus pertama hasil kerja dari mahasiswa melalui lembar kerja mahasiswa tentang bagaimana menuliskan kembali peristiwa sejarah yang berasal dari beberapa sumber masih cenderung menyalin dan belum banyak terlihat ide dan bahasa dari mahasiswa sendiri sebagai bentuk interpretasi. Sedangkan pada pembelajaran siklus yang ke dua hasil kerja mahasiswa mengalami perbaikan. Hasil kerja mahasiswa sudah mulai nampak ide dan gagasan dari mahasiswa sebagai bentuk interpretasi yang merupakan syarat dalam penulisan peristiwa sejarah yang baik.

\section{SIMPULAN DAN SARAN Simpulan}

Berdasarkan hasil penelitian mengenai Implementasi model pembelajaran historiografi sosial pada perkuliahan sejarah sosial dapat diambil simpulan sebagai berikut:
1. Implementasi model pembelajaran historiografi sosial pada perkuliahan sejarah sosial terbukti dapat memperbaiki dan meningkatkan aktivitas belajar mahasiswa

2. Implementasi model pembelajaran historiografi sosial pada perkuliahan sejarah sosial terbukti dapat meningkatkan prestasi belajar mahasiswa program studi pendidikan sejarah UM Metro

3. Mengajar menggunakan model pembelajaran historiografi sosial pada perkuliahan sejarah sosial dapat memperbaiki aktivitas dan meningkatkan prestasi belajar mahasiswa.

\section{Saran}

Berdasarkan hasil penelitian membuktikan bahwa Implementasi model pembelajaran historiografi sosial pada perkuliahan sejarah sosial dapat meningkatkan aktivitas dan prestasi belajar mahasiswa, maka peneliti sarankan beberapa hal sebagai berikut: 
1. Bagi Mahasiswa

Bagi mahasiswa disarankan untuk aktif dan kreatif membantu serta mendukung dosen pengajar dalam menggunakan model pembelajaran yang bervariasi guna memperbaiki aktivitas dan meningkatkan prestasi belajar mahasiswa.

2. Bagi Dosen Pengajar Implementasi model pembelajaran historiografi sosial pada perkuliahan sejarah sosial dirasa cocok untuk meningkatkan kemampuan menulis sejarah mahasiswa sehingga dosen lain dapat menggunakan model pembelajaran ini dalam menyampaikan materi pada mata kuliah yang serupa.

3. Bagi Program Studi Pendidikan Sejarah

$\begin{array}{lrr}\text { Bagi program } & \begin{array}{r}\text { studi } \\ \text { pendidikan }\end{array} \\ \text { disarankan untuk } & \text { dapat } \\ \text { mendukung dosen } & \text { dan } \\ \text { mengarahkan dosen } & \text { untuk } \\ \text { dapat menggunakan } & \text { model } \\ \text { pembelajaran yang bervariasi }\end{array}$

guna memperbaiki dan meningkatkan prestasi belajar mahasiswa. Dengan hal ini maka kinerja dosen dalam mengajar dapat lebih baik.

\section{Daftar Pustaka}

Suharsimi Arikunto. 2010. Penelitian Tindakan Kelas. PT Bumi Aksara. Jakarta

Basrowi dan Suwandi. 2008. Memahami Penelitian Kualitatif. Rineka Cipta. Jakarta

Karwono dan Heni Mularsih. 2012. Belajar dan Pembelajaran. Jakarta. PT Rajagrafindo Persada

Sukidin. 2008. Manajemen Penelitian Tindakan Kelas. Insan Cendekia. Surabaya 